\title{
Faktor-faktor yang Mempengaruhi Keberhasilan Implementasi Sistem Informasi Akuntansi pada Bank Muamalat di Kabupaten Jember
}

\author{
Kholidiyyah Ainur Latif ${ }^{*}$, Diyah Probowulan², Nina3 \\ 1,2,3 Program Studi Akuntansi Fakultas Ekonomi Universitas Muhammadiyah Jember
}

\author{
A R T I C L E I N F O \\ Article history: \\ Received 19 August 2019 \\ Received in revised form \\ 16 September 2019 \\ Accepted 15 October 2019 \\ Available online 30 \\ November 2019

\begin{tabular}{l}
\hline Kata Kunci: \\
Kualitas Sistem, Kualitas \\
Informasi, Kualitas \\
Layanan, Kepuasan \\
Pengguna \\
\\
Keywords: \\
System Quality, Information \\
Quality, service Quality, User \\
Satisfaction
\end{tabular}

\section{Kata Kunci:} \\ ualitas Sistem, Kualitas \\ Layanan, Kepuasan \\ Pengguna \\ Satisfaction
}

\begin{abstract}
A B S T R A K
Penelitian ini bertujuan untuk membuktikan pengaruh Sistem Kualiatas (kualitas sistem), Kualitas Informasi (kualitas informasi), Kualitas Layanan (kualitas layanan) terhadap Kepuasan Pengguna (kepuasan pengguna) dalam Sistem Informasi Akuntansi secara parsial. Jenis penelitian ini adalah deskriptif kuantitatif. Populasi penelitian ini adalah karyawan bank yang menggunakan sistem informasi akuntansi di Bank Muamalat di Kabupaten Jember, yang berjumlah 22 orang yang dijadikan sampel dalam penelitian ini. Data dikumpulkan menggunakan kuesioner dan alat dokumentasi, sedangkan analisis data dilakukan dengan menggunakan analisis regresi linier berganda yang menghasilkan $Y=20.126+0.111 X 1+-0.354 X 2+0.062 X 3$. Dari hasil uji $\mathrm{t}$ (parsial) sistem mutu terdapat nilai 0,698 <t tabel 2,101 dan nilai signifikansi $0,493>0,05$, yang berarti bahwa hipotesis kualitas sistem tidak mempengaruhi kepuasan pengguna dalam sistem. Informasi akuntan. Dan dari variabel Kualitas Informasi (kualitas informasi) terdapat nilai $-1,440<$ ttabel 2,101 dan nilai signifikansi $0,165>0,05$, yang berarti bahwa hipotesis Kualitas Informasi tidak mempengaruhi
\end{abstract} kepuasan pengguna dalam Sistem Informasi Akuntansi. Demikian juga, variabel kualitas layanan memiliki nilai $-0,397<$ ttabel 2,101 dan nilai signifikansi 0,696>0,05 yang berarti bahwa hipotesis kualitas layanan tidak mempengaruhi kepuasan pengguna dalam Sistem Informasi Akuntansi.

\section{A B S T R A C T}

This study aims to prove the influence of Kualiatas System (system quality), Information Quality (information quality), Quality of Service (service quality) on User Satisfaction (user satisfaction) in Accounting Information Systems partially. This type of research is descriptive quantitative. The population of this study is bank employees who use accounting information systems at Bank Muamalat in Jember Regency, which amount to 22 people who were used as samples in this study. Data collected using questionnaires and documentation tools, while data analysis was carried out using multiple linear regression analysis which results $Y=20.126+0.111 X 1+-0.354 X 2+0.062 X 3$. From the results of the $t$ (partial) test of the quality system there is a value of $0.698<t$ table 2.101 and a significance value of $0.493>0.05$, which means that the system quality hypothesis does not affect user satisfaction in the system. Accounting Information. And from the variable Quality of Information (information quality) there is a value of $-1.440<$ ttable 2.101 and a significance value of $0.165>0.05$, which means that the Information Quality hypothesis does not affect user satisfaction in the Accounting Information System. Likewise, the service quality variable has a value of $-0.397<$ ttable 2.101 and a significance value of $0.696>0.05$ which means that the service quality hypothesis does not affect user satisfaction in the Accounting Information System.

\footnotetext{
* Corresponding author.

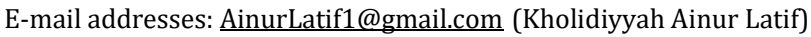




\section{Pendahuluan}

Teknologi informasi dapat membantu segala jenis bisnis. Meningkatkan efisiensi dan efektivitas proses bisnis, pengambilan keputusan manajerial, dan kerjasama kelompok kerja, hingga dapat memperkuat posisi kompetitif dalam pasar yang cepat sekali berubah. Hal ini berlaku ketika teknologi informasi digunakan untuk mendukung tim pengembangan produk, proses dukungan untuk pelanggan, transaksi e-commerce, atau dalam aktivitas bisnis lainnya (O'Brien, 2006). Teknologi informasi sendiri dapat diartikan sebagai teknologi yang menggabungkan komputasi (jaringan komputer) dengan jalur komunikasi yang membawa data, suara, ataupun video (Williams dan Sawyer, 2003). Salah satu peran teknologi informasi bagi perusahaan adalah dengan berkembangnya produk dan layanan yang diciptakan untuk memenuhi kebutuhan masyarakat luas. Teknologi informasi tersebut berada di dalam sistem perusahaan.

Semakin tinggi kecanggihan suatu teknolgi maka semakin tinggi juga masalah yang mungkin timbul akibat dari adanya teknologi tersebut. Tidak jarang ditemukan bahwa teknologi yang diterapkan dalam sistem informasi kurang memberikan manfaat dalam meningkatkan kinerja individual (Irwansyah, 2003). Masalah yang biasanya terjadi dalam pemakaian paket sistem informasi adalah tidak kompatibelnya sistem dengan proses bisnis dan informasi yang diperlukan organisasi (Janson dan Subramanian, 1996; Lucas, Walton, dan Ginzberg, 1998). Jika sistem informasi tidak dimanfaatkan secara maksimal atau sistem informasi kurang mampu memberikan hasil yang diharapkan maka akan berdampak pada organisasi perusahaan secara keseluruhan. Penerapan teknologi informasi perusahaan hendaknya mempertimbnagkan pemakai sistem sehingga teknologi yang diterapkan dapat bermanfaat sesuai dengan tugas dan kemampuan pegawai.

Hubungan antara manusia sebagai pengguna sistem dan aplikasi perangkat lunak sebagai objek merupakan hubungan yang tidak terpisahkan. Pengguna yang menentukan aplikasi tersebut layak dipakai atau tidak. Jika pengguna merasa bahwa aplikasi tersebut tidak berkualitas dan tidak mampu memenuhi kebutuhan, maka aplikasi tersebut tidak layak digunakan. Dan pengguna akan mencari cara agar aplikasi tersebut diganti atau di-upgrade menjadi aplikasi yang lebih efektif dan lebih efisien dibanding dengan aplikasi yang lama.

Pengukuran kesuksesan sistem informasi bisa bervariasi tergantung dengan tujuan dari penerapan sistem informasi, oleh karena itu tidak ada ukuran pasti untuk kualitas sistem yang universal (Delone dan Mclean, 2016). Kualitas sistem digunakan untuk mengukur kualitas sistem itu sendiri, baik software maupun hardware. Kualitas sistem adalah performa dari sistem yang merujuk pada seberapa baik kemampuan perangkat keras, perangkat lunak, kebijakan, prosedur dari sistem informasi dapat menyediakan informasi kebutuhan pengguna (Delone dan Mclean, 1992).

Penelitian ini akan mengunakan Model Delone dan McLean sebagai referensi dalam penentuan variabel independent pada Bank Syariah di Kabupaten Jember yaitu, Bank Muamalat. Berdasarkan survei pendahuluan diketahui bahwa pengguna sistem informasi akuntansi (pegawai bank) pada bank tersebut merasa kurang puas dengan kinerja sistem informasi akuntansi yang mereka gunakan. Selain itu, alasan peneliti masih memilih bank sebagai objek penelitian karena dari penelitian terdahulu objek yang digunakan adalah Bank, sehingga hasil penelitian diharapkan mampu bersifat valid seperti penelitian sebelumnya. Selanjutnya, yang menjadi perbedaan penelitian ini dengan penelitian terdahulu terlihat dari sisi objek penelitian yang digunakan. Kalau pada penelitian terdahulu, objek penelitian yang digunakan hanya bersifat menguji keberhasilan Sistem Informasi Akuntansi antara bank konvensional saja. Akan tetapi, pada penelitian ini yang digunakan sebagai objek adalah Bank Syariah.

Berdasarkan latar belakang diatas, maka peneliti akan melakukan penelitian mengenai Faktorfaktor yang Mempengaruhi Keberhasilan Implementasi Sistem Informasi Akuntansi pada Bank Muamalat di Kabupaten Jember. Jenis penelitian ini deskriptif kuantitatif. Populasi penelitian ini adalah Pegawai bank yang menggunakan sistem informasi akuntasi pada Bank Muamalat di Kabupaten Jember, yang berjumlah 22 orang yang digunakan sebagai sampel dalam penelitian ini. Dalam penelitian ini analisis data dilakukan dengan menggunakan analisis regresi linier berganda. Dan menggunakan uji t untuk mengetahui bagaimana pengaruh antar variabel.

Rumusan masalah dan tujuan penelitian ini adalah untuk membuktikan apakah dari ke empat variabel tersebut berpengaruh atau tidak terhadap kepuasan pengguna dalam sistem informasi akuntansi. Sedangkan manfaat dari penelitian ini adalah mampu memberikan tambahan pengetahuan dan dapat digunakan untuk menambah referensi dalam meningkatkan sistem informasi akuntansi bank agar lebih baik lagi, serta bisa memberikan kontribusi dalam menambah pengetahuan dibidang sistem informasi akuntansi untuk menjadi acuan penelitian selanjutnya.

Radityo dan Zulaikha (2007) dalam penelitiannya yang berjudul Pengujiian Kesuksesan Sistem Informasi Menggunakan Model Delone Dan Mclean. Hasil penelitian menunjukkan bahwa use memiliki 
hubungan positif dengan individual impact dan individual impact memiliki hubungan positif dengan organizational impact serta tidak terdapat hubungan positif antara information quality, system quality, terhadap use dan user satisfaction.

Hudin dan Riana (2016) dalam penelitiannya yang berjudul Kajian Keberhasilan Penggunaan Sistem Informasi Accurate dengan menggunakan Model Kesuksesan Sistem Informasi Delone dan McLean. Hasil dari penelitian ini yakni kualitas informasi berpengaruh signifikan terhadap kepuasan pengguna, kualitas sistem berpengaruh signifikan terhadap kepuasan pengguna, kualitas pelayanan berpengaruh signifikan terhadap kepuasan pengguna, pengguna berpegaruh signifikan terhadap kepuasan pengguna, pengguna berpengaruh signifikan terhadap manfaat bersih.

Juhari Livari (2005) dalam penelitiannya yang berjudul An empirical test of the Delone-mclean Model of information System Success. Menguji Model Delone Dan Mclean dengan field study atas system information mandatory. Menemukan bahwa system quality dan information quality memiliki hubungan yang signifikan terhadap user satisfaction. System quality memiliki hubungan yang signifikan terhadap use dan user satisfaction terhadap individual impact.

Menurut Bodnar dan Hopwood (2006:3) sistem Informasi Akuntansi merupakan kumpulan sumber daya seperti manusia dan peralatan yang dirancang untuk mengubah data keuangan dan data lainnya ke dalam informasi. Salah satu komponen dari sistem informasi akuntansi yaitu teknologi. Hadirnya teknologi dapat membantu manajer perusahaan dalam kegiatan organisasi bisnis.

Menurut Romney dan Steinbart (2014:11) ada enam komponen Sistem Informasi Akuntasi adalah sebagai berikut : a) Orang yang menggunakan system, b)Prosedur dan instruksi yag digunakan untuk mengumpulkan, memproses, dan menyimpan data, c) Data mengenai organisasi dan aktivitas bisnisnya, d) Perangkat lunak yang digunakan untuk mengolah data, e) Infrastruktur teknologi informasi, meliputi Komputer, perangkat peripheral, dan perangkat jaringan komunikasi yang digunakan dalam Sistem Informasi Akuntasi, dan f) Pengendalian Internal dan pengukuran keamanan yang menyimpan data Sistem Informasi Akuntasi.

Sukses atau tidaknya suatu sistem teknologi informasi dalam organisasi tergantung beberapa faktor. Terdapat banyak pilihan model untuk mengukur keberhasilan dalam suatu sistem informasi yang dikembangkan oleh peneliti. Model yang baik adalah model yang lengkap tetapi sederhana. Pada tahun 1992 Delone dan McLean mengemukakan teori tentang kesuksesan sistem informasi yang dikenal dengan D\&M IS Success Model. Model kesuksesan sistem informasi yang dikembangkan oleh Delone dan McLean (1992) ini banyak mendapat perhatian dan cepat mendapat tanggapan. Sebabnya adalah model mereka merupakan model yang sederhana tetapi dianggap cukup valid oleh peneliti. Model Delone dan McLean (1992) berdasarkan kajian teoritis dan empiris mengenai sistem informasi yang tercipta oleh para peneliti pada sekitar tahun 1970-an dan 1980-an. Model kesuksesan Delone dan McLean (1992) didasarkan pada proses hubungan kausal dari dimensi-dimensi di model.

Suatu model kesuksesan sistem informasi akuntansi dikatakan sukses apabila dari pengguna sistem mau menggunakan sistem tersebut dan juga memberikan kepuasan pengguna sebagaimana fungsi dari sistem tersebut. Cara menganalisisnya, yang pertama kali dilakukan adalah menilai kondisi sistem. Penilaian ini ditentukan oleh kualitas sistem, kualitas informasi, dan kualitas pelayanan yang dihasilkannya. Keberadaan sistem informasi akuntansi akan mempengaruhi perilaku pengguna. Untuk mengetahui perilaku pengguna dinilai dari penggunaan sistem dan kepuasan terhadap sistem. Perilaku pengguna ditentukan oleh variabel penggunaan sistem dan kepuasan pengguna. Penggunaan yang berulang-ulang dapat dimaknai bahwa penggunaan yang dilakukan bermanfaat bagi pengguna. Tingginya manfaat yang di peroleh mengakibatkan pengguna akan lebih puas menggunakan sistem.

Menurut Undang-undang Negara Republik Indonesia Nomor 10 tahun 1998 tentang perbankan, yang dimaksud dengan bank adalah badan usaha yang menghimpun dana dari masyarakat dalam bentuk simpanan dan menyaalurkannya kepada masyarakat dalam bentuk kredit dan atau bentuk-bentuk lainnya dalam rangka meningkatkan taraf hidup rakyat banyak. Perbankan sendiri diartikan sebagai industi lembaga keuangan yang ada di dalam suatu Negara.

Struktur perbankan di Indonesia, terdiri atas Bank Umum dan Bank Perkreditan Rakyat (Data BI). Antara bank umum dengan BPR mempunyai banyak perbedaan. Perbedaaan utama bank umum dengan BPR adalah dalam hal kegiatan operasionalnya. BPR tidak dapat menciptakan uang giral, dan memiliki jangkauan dan kegiatan operasional yang terbatas. Sedangkan pada Bank umum, dapat menciptakan uang giral, dan memiliki jangkauan dan kegiatan operasional yang lebih luas dibanding dengan BPR. 


\section{Kerangka Penelitian}

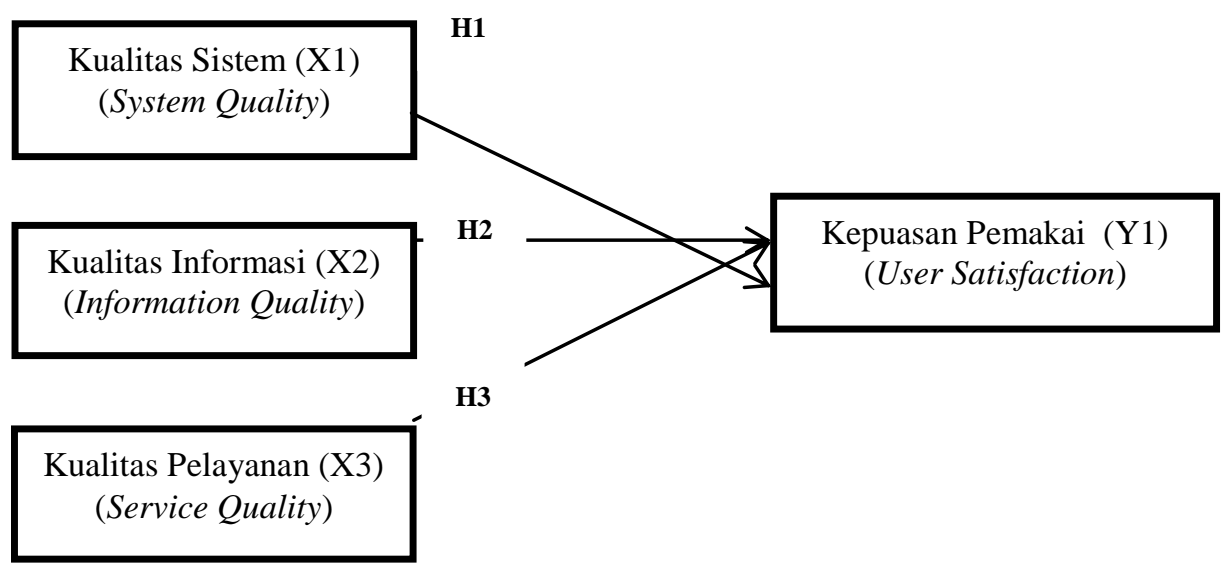

Kualitas Sistem (system quality) berpengaruh terhadap kepuasan pengguna (user satisfaction) sistem informasi akuntansi.

Salah satu indikator kesuksesan sistem informasi adalah kualitas sistem itu sendiri (Radityo dan Zulaikha, 2007). Kualitas sistem merupakan karakteristik dari informasi yang melekat mengenai sistem itu sendiri (Delone dan McLean, 1992). Menurut penelitian terdahulu yang dikemukakan oleh Istianingsih dan Utami (2009), semakin tinggi kualitas sistem yang digunakan, diprediksi akan berpengaruh terhadap semakin tingginya tingkat kepuasan pengguna sistem tersebut.

Kualitas Informasi (information system) berpengaruh terhadap Kepuasan Pengguna (user satisfaction) sistem informasi akuntansi.

Kesukesan sebuah sistem informasi dipengaruhi oleh kualitas dari informasi. kualitas informasi dapat memberikan dampak yang signifikan terhadap individu. Dampak positif yang diharapkan antara lain peningkatan kemampuan dalam pengambilan keputusan, kefektifan kerja dan peningkatan kualitas kerja (Delone dan McLean, 2003). Seddon dan Kiew (1996) telah melakukan pengujian mengenai pengaruh dari kualitas informasi ini terhadap kepuasan pegguna sistem informasi. Hasil pengujian mereka menunujukkan bahwa kualitas informasi berhubungan positif dengan kepuasan pengguna sistem informasi.

Kualitas Pelayanan (service quality) berpengaruh terhadap Kepuasan Pengguna (user satisfaction) sistem informasi akuntansi. Kualitas pelayanan menjadi lebih penting dibandingkan penerapan lainnya, karena pemakai-pemakai sistem sekarang adalah lebih sebagai para pelanggan dan bukannya para karyawan atau pemakai internal organisasi. Menurut hasil penelitian Hudin dan Riana (2016) menyatakan bahwa kualitas pelayanan berpengaruh signifikan terhadap kepuasan pengguna.

\section{Metode}

Pada penelitian ini, jenis data yang digunakan adalah data primer. Menurut Sekaran (2014:113) data primer mengacu pada informasi yang diperoleh dari tangan pertama oleh peneliti terhadap variabel minat untuk tujuan spesifik dari suatu studi. Data primer dalam penelitian ini akan diperoleh langsung dari responden melalui pembagian kuesioner kepada pegawai pengguna (user) yang menggunakan sistem informasi akuntansi. Pengumpulan data dilakukan dengan survei dan memabagikan kuesioner. Teknik ini memberikan tanggung jawab kepada responden untuk membaca dan menjawab pertanyaan. Dalam penelitian ini, kuesioner didistribusikan secara langsung oleh peneliti dibantu oleh tenaga lapangan. Objek penelitian adalah semua pengguna Sistem Informasi Akuntansi pada Bank Muamalat Di Kabupaten Jember.

Populasi dalam penelitian ini adalah semua pengguna Sistem Informasi Akuntansi pada Bank Muamalat Di Kabupaten Jember dengan jumlah sampel didapatkan 22 responden. Teknik analisis data terdiri dari uji reliabilitas dan uji validitas. Metode analisis data terdiri dari uji analisis regresi linier berganda, uji normalitas, uji multikolinearitas, uji heteroskedastisitas. Pengujian hipoteisis menggunakan uji Parsial (uji t), dan koefisien determinasi. 


\section{Hasil dan pembahasan}

Uji validitas dan reliabilitas dalam penelitian ini dilakukan dengan menggunakan fasilitas program SPSS 21. Uji validitas dilakukan untuk mengukur kualitas instrument variabel Kualiatas Sistem (system quality), Kualitas Informasi (information quality), Kualiatas Pelayanan (service quality) terhadap Kepuasan Pengguna (user satisfaction) dalam Sistem Informasi Akuntansi yang diuji cobakan kepada 22 responden. Dari hasil uji coba yang telah diuji validitas dan reliabilitasnya, diketahui bahwa semua instrumen dinyatakan valid dan reliabel

Metode Analisis Data

1. Analisis regresi linier berganda

Uji regresi linier bertujuan untuk menghitung seberapa besar pengaruh variabel bebas terhadap variabel terikat. Menurut Gujarati dalam Ghozali (2006:81) menerangkan bahwa analisis regresi pada dasarnya adalah studi mengenai ketergantungan variabel dependen (terikat) dengan satu atau lebih variabel independen (variabel bebas), dengan tujuan untuk mengestimasi atau memprediksi rata-rata populasi atau nilai rata-rata variabel dependen berdasarkan nilai variabel independen yang diketahui. Hasil penelitian menunjukkan bahwa masing-masing variabel bebas memiliki hubungan linier dengan variabel terikat.

2. Uji Normalitas

Uji normalitas pada model regresi digunakan untuk menguji apakah nilai residual yang dihasilkan dari regresi terdistribusi secara normal atau tidak. Metode uji normalitas yang digunakan dalam penelitian ini yaitu dengan melihat uji One-Sample Kolmogorov-Smirnov. Berdasarkan hasil uji OneSample Kolmogorov-Smirnov dapat diketahui bahwa tingkat signifikansi sebesar 0,751, hasil tersebut menunjukkan bahwa data terdistribusi secara normal.

3. Uji Multikolinearitas

Uji multikolinearitas bertujuan untuk menguji apakah dalam model regresi ditemukan adanya korelasi antarvariabel independen. Untuk mengetahui ada tidaknya korelasi antar variabel, dilihat dari nilai VIF (Variance Inflation Factor). Hasil penelitian menunjukkan bahwa variabel Kualiatas Sistem nilai VIF sebesar 1.026, variabel Kualitas Informasi nilai VIF sebesar 1.186, variabel Kualitas Pelayanan nilai VIF sebesar 1.178. Nilai VIF pada keseluruhan model regresi menghasilkan nilai VIF < 10, hasil tersebut menunjukkan tidak dijumpai gejala multikolinearitas antar variabel.

4. Uji Heteroskedastisitas

Uji heteroskedastisitas bertujuan untuk menguji apakah dalam sebuah model regresi terjadi ketidaksamaan varians dari residual pada satu pengamatan ke pengamatan lain. Salah satu cara untuk mendeteksi ada tidaknya heteroskedastisitas dapat dilakukan dengan melihat grafik plot antara nilai prediksi variabel dependen yaitu ZPRED dengan residualnya SRESID. Berdasarkan pengamatan terhadap scatterplot dapat diketahui bahwa titik-titik tidak membentuk pola yang jelas. Titik- titik menyebar di atas dan dibawah pada sumbu Y. jadi dapat disimpulkan bahwa tidak terjadi masalah heteroskedastisitas dalam model regresi.

5. Uji t

Uji t digunakan untuk mengetahui pengaruh variabel bebas terhadap variabel terikat secara parsial yaitu pengaruh masing-masing variabel Kualitas Sistem (system quality), Kualitas Informasi (information quality), Kualitas Pelayanan (service quality) terhadap Kepuasan Pengguna (user satisfaction) dalam Sistem Informasi Akuntansi. Hasil uji parsial Kualitas Sistem dapat dilihat bahwa nilai t-hitung lebih kecil dari t-tabel $(0,698<2.101)$ dengan signifikansi 0,493 . Hal tersebut menunjukkan bahwa tidak terdapat pengaruh antara kualitas sistem dengan kepuasan pengguna dalam menggunakan sistem informasi akuntansi. Nilai positif dalam t-hitung mengindikasikan bahwa terdapat hubungan yang positif. Hasil uji parsial Kualitas Informasi dapat dilihat bahwa nilai t-hitung lebih kecil dari t-tabel $(-1.440<2.101)$ dengan signifikansi 0,165 . Hal tersebut menunjukkan bahwa tidak terdapat pengaruh antara kualitas informasi dengan kepuasan pengguna dalam menggunakan sistem informasi akuntansi. Nilai negatif dalam t-hitung mengindikasikan bahwa terdapat hubungan yang negatif. Hasil uji parsial Kualitas Pelayanan dapat dilihat bahwa nilai t-hitung lebih kecil dari ttabel $(-0,397<2.101)$ dengan signifikansi 0,696. Hal tersebut menunjukkan bahwa tidak terdapat pengaruh antara kualitas Pelayanan dengan kepuasan pengguna dalam menggunakan sistem informasi akuntansi. Nilai negatif dalam t-hitung mengindikasikan bahwa terdapat hubungan yang negatif.

6. Uji Koefisien Determinan

Koefisien determinasi mengukur seberapa jauh kemampuan model regresi dalam menerangkan variasi variabel Kualitas Informasi (information quality), Kualitas Pelayanan (service quality) terhadap Kepuasan Pengguna (user satisfaction) dalam Sistem Informasi Akuntansi. Hasil uji determinasi Kualitas Sistem besarnya $R$ Square adalah 0,024 hal ini berarti 2,4\% variabel dapat dijelaskan oleh 
Kualitas Sistem sedangkan sisanya sebesar 97,6\% dipengaruhi oleh variabel lain. Hasil uji determinasi Kualitas Informasi besarnya $R$ Square adalah 0,094 hal ini berarti 9,4\% variabel dapat dijelaskan oleh Kualitas Informasi sedangkan sisanya sebesar 90,6\%. di pengaruhi oleh variabel lain. Hasil uji determinasi Kualitas Pelayanan besarnya $R$ Square adalah 0,008 hal ini berarti 0,8\% variabel dapat dijelaskan oleh Kualitas Pelayanan, sedangkan sisanya sebesar 99,2\% di pengaruhi oleh variabel lain.

Kualitas Sistem (system quality) X1 berpengaruh terhadap kepuasan pengguna (user satisfaction) Y sistem informasi akuntansi.

Sistem informasi merupakan seperangkat komponen yang saling berhubungan yang berfungsi mengumpulkan, memproses, menyimpan, dan mendistribusikan informasi untuk mendukung pembuatan keputusan dan pengawasan dalam organisasi. Proses desain sistem informasi diharapkan dapat berfungsi secara efektif. Kefektifan ini juga mendanakan bahwa pengembangan sistem informasi tersebut sukses. Salah satu indikator kesuksesan sistem informasi adalah kualitas sistem itu sendiri (Radityo dan Zulaikha, 2007). Kualitas sistem merupakan karakteristik dari informasi yang melekat mengenai sistem itu sendiri (Delone dan McLean, 1992).

Pada hasil uji regresi menunjukkan bahwa tidak terdapat pengaruh antara kualitas sistem (system quality) dengan kepuasan pengguna (user satisfaction) sistem informasi akuntansi. Hal ini ditunjukkan bahwa nilai t-hitung lebih kecil dari t-tabel $(0,698<2.101)$ dengan tingkat signifikansi 0,493 . Artinya bahwa kualitas sistem (system quality) tidak berpengaruh terhadap Kepuasan Pengguna (user satisfaction) dalam sistem informasi akuntansi. Hasil penelitian ini tidak konsisten dengan penelitian yang dilakukan Istianingsih dan Utami (2009).

Hasil tersebut dijadikan patokan bahwa Kualitas Sistem (system quality) akan berdampak pada rendahnya Kepuasan Pengguna (user satisfaction) dalam sistem informasi akuntansi. Kurangnya minat para pegawai bank dalam menggunakan sistem informasi akuntansi.

Kualitas Informasi (information system) X2 berpengaruh terhadap Kepuasan Pengguna (user satisfaction) Y sistem informasi akuntansi.

Kesukesan sebuah sistem informasi dipengaruhi oleh kualitas dari informasi. kualitas informasi dapat memberikan dampak yang signifikan terhadap individu. Dampak positif yang diharapkan antara lain peningkatan kemampuan dalam pengambilan keputusan, kefektifan kerja dan peningkatan kualitas kerja (Delone dan McLean, 2003). Semakin baik kualitas informasi akan semakin tepat pula keputusan yang diambil. Apabula informasi yang dihasilkan tidak berkualitas, maka akan berpengaruh negatif pada kepuasan pemakain (Istianingsih dan Utami, 2009). Seddon dan Kiew (1996) telah melakukan pengujian mengenai pengaruh dari kualitas informasi ini terhadap kepuasan pegguna sistem informasi.

Pada hasil uji regresi menunjukkan bahwa tidak terdapat pengaruh antara Kualitas Informasi (information system) dengan Kepuasan Pengguna (user satisfaction) sistem informasi akuntansi. Hal ini ditunjukkan bahwa nilai t-hitung lebih kecil dari t-tabel $(-1.440<2.101)$ dengan tingkat signifikansi 0,165. Artinya bahwa Kualitas Informasi (information system) tidak berpengaruh terhadap Kepuasan Pengguna (user satisfaction) dalam sistem informasi akuntansi. Hasil penelitian ini tidak konsisten dengan penelitian yang dilakukan Jumardi et al. (2003).

Hasil tersebut dijadikan patokan bahwa Kualitas Informasi (information system) akan berdampak pada rendahnya Kepuasan Pengguna (user satisfaction) dalam sistem informasi akuntansi. Kurangnya minat para pegawai bank dalam menggunakan sistem informasi akuntansi.

Kualitas Pelayanan (service quality) X3 berpengaruh terhadap Kepuasan Pengguna (user satisfaction) Y sistem informasi akuntansi.

Kualitas Pelayanan (service quality) menurut Parasuraman (1998) didasarkan pada perbandingan antara apa yang seharusnya ditawarkan (offered) dan apa yang disediakan (provided). Kualitas Pelayanan yang baik adalah kualitas yang memberikan tanggapan, jaminan dan empati untuk memenuhi harapan penggunaan sistem. Semakin tinggi kualitas pelayanan, maka semakin tinggi kepuasan pengguna sistem informasi akuntansi. Sehingga sistem dikatakan sukses apabila kualitas pelayanan yang diberikan oleh pihak pengembang sistem dapat memberikan respon dan memenuhi kebutuhan pengguna, dimana pengguna akan puas menggunakan sistem informasi. Menurut Masrek et al (2000) menyatakan bahwa penelitiannya tentang kualitas layanan memiliki pengaruh yang signifikan terhadap kepuasan pengguna. Kualitas pelayanan menjadi lebih penting dibandingkan penerapan lainnya, karena pemakai-pemakai sistem sekarang adalah lebih sebagai para pelanggan dan bukannya para karyawan atau pemakai internal organisasi.

Pada hasil uji regresi menunjukkan bahwa tidak terdapat pengaruh antara Kualitas Pelayanan (service quality) dengan Kepuasan Pengguna (user satisfaction) sistem informasi akuntansi. Hal ini ditunjukkan bahwa nilai t-hitung lebih kecil dari t-tabel $(-0,397<2.101)$ dengan tingkat signifikansi 0,696. Artinya bahwa Kualitas Pelayanan (service quality) tidak berpengaruh terhadap Kepuasan Pengguna (user 
satisfaction) dalam sistem informasi akuntansi. Hasil penelitian ini tidak konsisten dengan penelitian yang dilakukan Jumardi et al. (2003).

Hasil tersebut dijadikan patokan bahwa Kualitas Pelayanan (service quality) akan berdampak pada rendahnya Kepuasan Pengguna (user satisfaction) dalam sistem informasi akuntansi. Kurangnya minat para pegawai bank dalam menggunakan sistem informasi akuntansi.

\section{Simpulan dan saran}

Hasil uji parsial Kualitas Sistem dapat dilihat bahwa nilai t-hitung lebih kecil dari t-tabel $(0,698<$ 2.101) dengan signifikansi 0,493 . Hal tersebut menunjukkan bahwa tidak terdapat pengaruh antara kualitas sistem dengan kepuasan pengguna dalam menggunakan sistem informasi akuntansi. Nilai positif dalam t-hitung mengindikasikan bahwa terdapat hubungan yang positif.

Hasil uji parsial Kualitas Informasi dapat dilihat bahwa nilai t-hitung lebih kecil dari t-tabel (-1.440 $<2.101$ ) dengan signifikansi 0,165. Hal tersebut menunjukkan bahwa tidak terdapat pengaruh antara kualitas informasi dengan kepuasan pengguna dalam menggunakan sistem informasi akuntansi. Nilai negatif dalam t-hitung mengindikasikan bahwa terdapat hubungan yang negatif.

Hasil uji parsial Kualitas Pelayanan dapat dilihat bahwa nilai t-hitung lebih kecil dari t-tabel $(-0,397$ $<2.101$ ) dengan signifikansi 0,696. Hal tersebut menunjukkan bahwa tidak terdapat pengaruh antara kualitas Pelayanan dengan kepuasan pengguna dalam menggunakan sistem informasi akuntansi. Nilai negatif dalam t-hitung mengindikasikan bahwa terdapat hubungan yang negatif.

Diharapkan untuk penelitian selanjutnya lebih diperluas lagi untuk populasi dan jumlah sampelnya agar hasil dari penelitiannya bisa valid dan benar-benar menguji terhadap pengaruh keberhasilan implementasi dari sistem informasi akuntansi.

Diharapkan untuk peneltian selanjutnya menggunakan model Delone dan Mclean dalam menguji keberhasilan implementasi dengan menggunakan sistem informasi akuntansi yang berbeda, yaitu antara konvensional dan syariah.

Diharapkan sistem informasi akuntansi di bank lebih ditingkatkan lagi agar pengguna dari sistem informasi akuntansi merasa puas dan bisa menggunakannya dengan baik.

\section{Daftar Rujukan}

Bailey, J.E. dan S.W. Pearson. 1983. Development of a Tool For Measuring And Analyzing Computer User Satisfaction. Management Science 29 (May).

Bondar, George H, and William S.Hopwood. 2006. Sistem Informasi Akuntansi, Buku I, Salemba Empat. Jakarta.

Delone, W., and McLean E.R. 1992. Information System Success : The Quest Fo The Dependent Variable. Information System Research.

Delone, W., and McLean E.R. 2003. The Delone And Mclean Model Of Information System Success : A Ten Year Update. Journal of MIS.

Delone, William H. and McLean, Epharaim R. 2016. Information System Success : The Quest For The Dependen Variable. Information System Research, Vol 3 : 60-95.

Doll, William dan Xiadong Den. 2011. The Collaborative Use of Information Technology : End User Participation and Systems Success. Information Resources Management Journals. ABI/INFORM Global.

Ghozali Imam. 2005. Model Persamaan Struktural : Konsep Dan Aplikasi Dengan Program Amos Versi 5.0. Badan Penerbit Univeritas Diponegoro. Isbn 979.704.233.2.

Ghozali Imam. 2006. Model Persamaan Struktural : Konsep Dan Aplikasi Dengan Program Amos Versi 5.0. Badan Penerbit Univeritas Diponegoro. Isbn 979.704.233.2.

Ghozali Imam. 2007. Model Persamaan Struktural : Konsep Dan Aplikasi Dengan Program Amos Versi 5.0. Badan Penerbit Universitas Diponegoro. ISBN 979.704.232.2. 
Gumaires, T., D.S. Staples, and J.D. McKeen.2003. Empirically Testing Some Main User -Related Factor for Systems Development Quality. Quality Management Journal 10, no 4.

Hartono, Jogiyanto. 2007. Analisis Dan Desain Sistem Informasi : Pendekatan Terstruktur Teori Dan Praktek Aplikasi Bisnis. Edisi Kedua. Andi Offset. Yogyakrta.

Istianingsih Dan Wijanto, Setyo Hari, 2008. Pengaruh Kepuasan Pengguna Sistem Informasi Terhadap Kinerja Individu (Studi Empiris Pada Pengguna Paket Program. Aplikasi Sistem Informasi Akuntansi Di Indonesia). Simposium Nasional Akuntansi XII. Palembang.

Istianingsih dan Utami. 2009. Pengaruh Kepuasan Pengguna Sistem Informasi Terhadap Kinerja Individu Pada Pengguna Sistem Informasi Akuntansi Di Indonesia. SNA XII. Palembang.

McKeen JD, Gumaires T and Wetherbe JC. 1994. The Relationship Between User Participation and User Satisfaction : An Investigation of Four Contingency Factors. MIS Quarterly.

Radityo, D., dan Zulaikha. 2007. Pengujian model delone dan McLean dalam pengembangan sistem informasi manajemen. Jurnal symposium nasional akuntansi.

Radityo, D., dan Zulaikha. 2007. Pengujian model delone dan McLean dalam pengembangan sistem informasi manajemen. Jurnal symposium nasional akuntansi.

Seddon, Petter B. 1997. A Respecification and Extension of The Delone and McLean Model of IS Success. Information Systems Research, vol. 8:240-253.

Sekaran, U. Research Methods for Bussiness : A Skill-Building Approach $4^{\text {th }}$. New Jersey : John Wiley and Sons, Ins., 2003.

Sugiyono, 2004. Metodologi Penelitian Kuantitatif Kualitatif Dan R\&D. Bandung : Alfabeta.

Sugiyono. 2010. Metode Penelitian Kuantitatif, Kualitatif, Kombinasi (Mixed Method). Bandung : Alfabeta.

Sugiyono. 2012. Metode Penelitian Kuantitatif, Kualitatif, Kombinasi (Mixed Method). Bandung : Alfabeta.

Suryaningrum, D. H. 2003. The Relationship Between User Participation And System Success : Study Of Three Contingency Factor on BUMN in Indonesia. Simposium nasional akuntansi. Surabaya.

Wahyu Winarno. 2006. Sistem Informasi Akuntansi Edisi Ke-2. Yogyakarta : UPP STIM YKPN. 